\title{
In Silico Study of Compounds Contained in Hemigraphis alternata Leaves against 5-LOX for Anti-Inflammatory
}

\author{
Yeni Yeni*, Rizky Rachmania, Mochamad D. Yanuar \\ Faculty of Pharmacy and Science, Universitas Muhammadiyah Prof. DR. HAMKA, Jakarta, Indonesia \\ Submitted 8 August 2020; Revised 20 September 2020; Accepted 20 October 2020; Published 05 February 2021 \\ *Corresponding author: yeni@uhamka.ac.id
}

\begin{abstract}
Inflammation is a self-protection response to begin the healing process. One of the anti-inflammatory targets worth developing is lipoxygenase inhibitors, which have been studied for several diseases, including severe airways disease. The aim of this study was to predict the affinity of 23 compounds that contained in Hemigraphis alternata leaves against 5-lipoxygenase (5-LOX). The compounds of Hemigraphis alternata leaves were screened for its affinity againts 5-LOX using docking software, DOCK 6.9, with zileuton as the comparator. Based on the grid score, most of the 23 of Hemigraphis alternata leaves compounds showed a higher affinity towards 5-LOX compare to zileuton. The highest affinity was shown by n-hexadecanoid acid. The study showed that Hemigraphis alternata leaves contains potential active components that could be developed as 5-LOX-inhibitor.
\end{abstract}

Keywords: In silico, Hemigraphis alternata, lipoxygenase, anti-inflammatory

\section{Studi In Silico Senyawa-Senyawa dari Daun Hemigraphis Alternata terhadap 5-LOX untuk Anti-Inflamasi}

\begin{abstract}
Abstrak
Inflamasi merupakan respon perlindungan tubuh untuk memulai proses penyembuhan. Salah satu target anti-inflamasi yang layak dikembangkan adalah penghambat lipoksigenase, yang telah dipelajari untuk beberapa penyakit, termasuk penyakit saluran napas yang parah. Tujuan dari penelitian ini adalah untuk memprediksi afinitas 23 senyawa yang terkandung dalam daun Hemigraphis alternata dalam menghambat 5-LOX. Senyawa-senyawa yang terkandung dalam daun Hemigraphis alternata diskrining afinitasnya terhadap 5-LOX menggunakan perangkat lunak penambatan molekul DOCK 6.9 dengan senyawa zileuton sebagai pembandingnya. Berdasarkan grid score, sebagian besar dari 23 senyawa daun Hemigraphis alternata menunjukkan afinitas yang lebih tinggi terhadap 5-LOX dibandingkan dengan zileuton. Afinitas tertinggi ditunjukkan oleh n-hexadecanoid acid. Hasil penelitian menunjukkan bahwa daun Hemigraphis alternata mengandung komponen aktif potensial yang dapat dikembangkan sebagai penghambat 5-LOX.
\end{abstract}

Kata Kunci: In silico, Hemigraphis alternata, lipoksigenase, anti-inflamasi 


\section{Pendahuluan}

Inflamasi adalah respon patofisiologis terhadap infeksi atau kerusakan jaringan. ${ }^{1}$ Proses biologis ini penting untuk pemberantasan patogen dan pemeliharaan homeostasis jaringan., ${ }^{2,3}$ Inflamasi biasanya merupakan cerminan dari kerusakan sel disebabkan oleh infeksi, cedera fisik atau respon jaringan terhadap penolakan antibodi. ${ }^{4}$ Gejala klinis inflamasi ditandai oleh rubor (kemerahan), kalor (panas), tumor (pembengkakan), dolor (nyeri) dan functio laesa (kehilangan fungsi). ${ }^{5}$

Hemigraphis alternata (remek daging) memiliki sejarah panjang sebagai etnomedisin untuk penyembuhan luka, dengan catatan yang berasal dari 3000 SM dalam teks-teks obat India kuno. ${ }^{6}$ Pada tumbuhan ini terkandung flavonoid yang diduga memberikan efek antiinflamasi. ${ }^{7,8}$ Terdapat 23 metabolit sekunder yang berhasil diisolasi pada tumbuhan ini. ${ }^{6}$

Target farmakologis dari obat antiinflamasi diantaranya 5-Lipoksigenase (5-LOX). ${ }^{9}$ LOX merupakan enzim yang memetabolisme asam arakidonat dan menghasilkan leukotrin yang merupakan mediator inflamasi. ${ }^{10,11}$

Studi in silico merupakan simulasi komputer individual untuk pengembangan atau evaluasi obat-obatan. ${ }^{12}$ Metode in silico dapat digunakan untuk memprediksi bagaimana obat mempengaruhi sistem biologis yang akhirnya dapat meningkatkan penggunaan klinis, menghindari efek samping dan memandukan pemilihan dan pengembangan pengobatan yang lebih baik. Studi ini memberi manfaat tambahan untuk menghasilkan hipotesis tentang mekanisme biologis obat atau penyakit dalam proses penemuan kandidat obat baru. ${ }^{13}$

Penambatan molekul memperlihatkan aktivitas molekul yang berukuran kecil di sisi pengikatan protein target. ${ }^{14,15}$ Hasil dari penambatan molekul berupa energi yang dibutuhkan oleh ligan untuk berikatan dengan protein, semakin sedikit energi yang dibutuhkan ligan untuk berikatan dengan protein target maka ligan akan semakin mudah berikatan dengan protein target. ${ }^{16}$

Tujuan penelitian ini adalah untuk memprediksi senyawa yang berkhasiat sebagai anti-inflamasi pada daun Hemigraphis alternata dengan afinitas yang lebih besar terhadap 5-LOX dibandingkan obat pembanding, zileuton melalui studi in silico. Dengan demikian, kanditat obat baru dapat didapatkan untuk obat anti-inflamasi.

\section{Metode}

2.1. Alat

Perangkat keras yang digunakan, yaitu seperangkat personal komputer dengan spesifikasi processor AMD-A4-9125 RADEON R3, 4 COMPUTE CORES 2C+2G (2CPUs) $\sim 2.3 \mathrm{GHz}$ yang memakai operating system windows 10 Home 64-bit dan operating system Linux Ubuntu 16.04 LTS 64-bit serta supercomputer dengan processor AMD Ryzen 7 3700X, GPU Nvidia GetForce dengan operating system ubuntu 20.04.

Pangkalan data sebagai bahan penelitian ini merujuk padaProtein Data Bank (http://www.rcsb.org/pdb), Pub-Chem (http:// PubChem.ncbi.nlm.nih.gov), dan perangkat lunak digunakan Chimera versi 1.13, DOCK versi 6.9 (pustaka), dan Discovery Studio Visualizer versi 17.2.0.16349 (pustaka).

\subsection{Bahan}

Struktur tiga dimensi (3D) reseptor 5-LOX (kode PDB 6n2w) (pustaka) diunduh dari Protein Data Bank. Struktur tiga dimensi (3D) 23 ligan dan zileuton diunduh dari PubChem.

\subsection{Prosedur Rinci}

Studi penambatan molekul dilakukan dengan menggunakan DOCK dengan metode penambatan molekul fleksibel. Tahap pertama dalam melakukan penambatan molekul menggunakan program DOCK yaitu dengan membuat permukaan reseptor menggunakan Chimera setelah itu melakukan pembuatan dan pemilihan spheres. Tujuan dari pembuatan spheres adalah untuk membuat cluster pada protein sehingga diketahui koordinat ikatan ligan-reseptor. Selanjutnya yaitu pembuatan box dan grid, lalu dilakukan penambatan molekul. ${ }^{16}$

Penambatan molekul ulang antara 
reseptor 5-LOX dengan ligan natifnya, NDGA (nordihydroguaretic acid) dilakukan terlebih dahulu untuk memvalidasi metode yang digunakan sehingga didapatkan Root Mean Square Deviation (RMSD) $\leq 2 \AA .{ }^{17}$ Validasi ini dilakukan untuk mengetahui bahwa sistem penambatan molekul yang digunakan dapat mendapatkan hasil yang mendekati konformasi ligan hasil kristalografi. ${ }^{16}$

Ligan-ligan uji dan pembanding, zileuton di-docking, Hasil yang ada berupa nilai grid score. Ligan yang memiliki grid score terkecil merupakan ligan terbaik karena energi yang digunakan untuk berikatan dengan reseptor semakin kecil. Setelah itu, dilakukan visualisasi hasil penambatan molekul dengan Discovery Studio Visualizer untuk melihat ikatan yang terbentuk antara ligan terbaik dengan reseptor 5-LOX.

\section{Hasil}

Penambatan molekul ulang 5-LOX dengan ligan natifnya, NDGA menghasilkan nilai RMSD 1,36 ̊. Afinitas senyawa-senyawa yang terkandung dalam daun Hemigraphis alternata untuk anti-inflamasi diketahui dari hasil penambatan molekul terhadap 5-LOX (Tabel 1). Pada hasil penambatan molekul, afinitas terbesar ditunjukkan oleh n-Hexadecanoic acid dengan grid score sebesar $-37,68 \mathrm{kkal} / \mathrm{mol}$. Hasil visualisasi penambatan molekul menunjukkan ikatanikatan kimia yang terbentuk antara senyawa dengan reseptor (Tabel 2). Kompleks senyawa n-Hexadecanoic acid dengan 5-LOX membentuk 1 ikatan hidrogen dan 1 ikatan hidrofobik (Gambar 1).

\section{Pembahasan}

Beberapa teknik yang dapat digunakan untuk skiring virtual 3D adalah pharmacophore-based virtual screening dan metode penambatan molekul. Pada pendekatan pharmacophore-based virtual screening dilakukan penyamaan pola interaksi 3D atau model pharmacophore obat dengan ligan dalam kompleks. Sedangkan metode penambatan molekul menggunakan strategi pencarian dengan fungsi skoring. ${ }^{18}$

Pharmacophore-based virtual screening tidak hanya menghasilkan pola interaksi dari struktur kompleks 3D, tetapi juga memungkinkan skrining virtual untuk mencari molekul potensial dari kumpulankumpulan senyawa. Pola interaksinya ditentukan oleh sifat donor dan akseptor ikatan hidrogen, gugus hidrofobik dan cincin aromatik dari senyawa yang berikatan dengan target biologis. Penyempurnaan hasil Pharmacophore-based virtual screening dilakukan dengan menerapkan sebagian besar penambatan molekul untuk mengonfirmasi efisiensi bagian yang terikat ke sisi pengikatan. ${ }^{18}$

Metode penambatan molekul yang digunakan pada DOCK 6.9 dengan algoritma bentuk molekuler ${ }^{19}$ di dalam penelitian adalah penambatan molekul fleksibel atau bisa juga disebut penambatan molekul lunak, yaitu backbone reseptor maupun ligan berada dalam keadaan bergerak. Terdapat 3 metode penambatan molekul, yaitu penambatan molekul rigid, penambatan molekul ligan fleksibel dan penambatan molekul fleksibel. ${ }^{20}$ Sebelum memulai studi penambatan

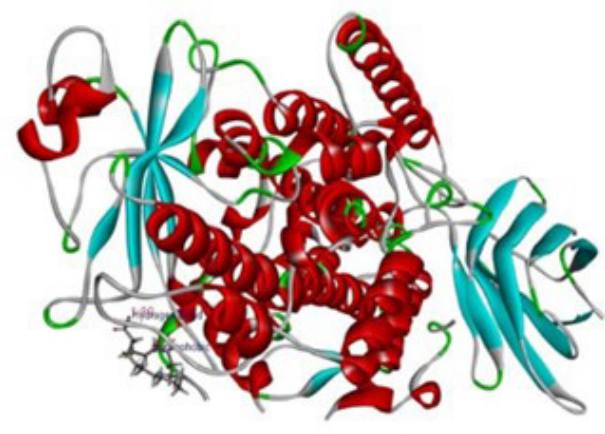

(a)

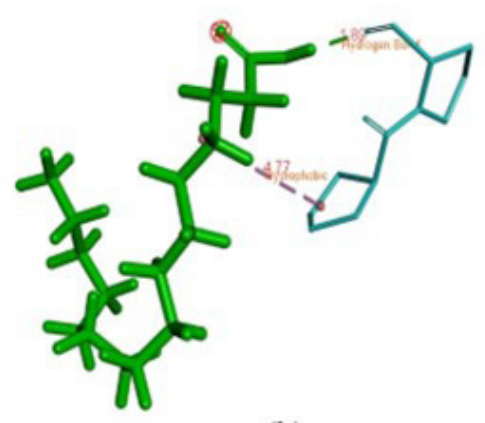

(b)

Gambar 1. Visualisasi hasil penambatan molekul kompleks n-hexadecanoic acid dan 5-LOX (a) 3D (b) 2D menggunakan Discovery Studio Visualizer versi 17.2.0.16349. 
Tabel 1. Hasil penambatan molekul senyawa uji terhadap 5-LOX menggunakan DOCK 6.9

\begin{tabular}{|c|c|c|c|c|c|}
\hline No & Senyawa & Grid Score & No & Senyawa & Grid Score \\
\hline 1 & $\begin{array}{l}\text { Zileuton (senyawa } \\
\text { pembanding) }\end{array}$ & $-26,19$ & 13 & Z-2-Dodecenol & $-27,28$ \\
\hline 2 & 15-Chloro-4-pentadecyne & $-25,90$ & 14 & 15-Chloro-4-pentadecyne & $-25,50$ \\
\hline 3 & $\begin{array}{l}\text { 4-(2-Methoxyphenyl) } \\
\text { piperidine }\end{array}$ & $-25,60$ & 15 & 2-Methylenecholestan-3-ol & $-31,62$ \\
\hline 4 & Cyclobutanol & $-12,86$ & 16 & L- Alanine & $-15,84$ \\
\hline 5 & 1-Hexadecyne & $-27,62$ & 17 & levodopa & $-30,38$ \\
\hline 6 & 2-Propylmanonic acid & $-21,69$ & 18 & Glycylsarcosine & $-22,65$ \\
\hline 7 & n-Hexadecanoic acid & $-37,68$ & 19 & 5-Hydroxymethylfurfural & $-20,94$ \\
\hline 8 & 2-Hexylacrylonitrile & $-21,67$ & 20 & 10-Undecyn-1-ol & $-22,86$ \\
\hline 9 & $\begin{array}{l}\text { 3,7,11-Trimethyl-1,6,10- } \\
\text { dodecatrien-3-ol }\end{array}$ & $-26,98$ & 21 & $\begin{array}{l}\text { 2,5-Dimethyl-2,3-dihydro-5H-1,4- } \\
\text { dioxepine }\end{array}$ & $-19,75$ \\
\hline 10 & $\begin{array}{l}\text { 8a-Methylhexahydro- } 1,8 \\
(2 \mathrm{H}, 5 \mathrm{H}) \text { - naphthalenedione }\end{array}$ & $-16,49$ & 22 & $\begin{array}{l}4 \text { - N i t r o - } 5 \text { - h y d r o x y - } 1,2 \text { - } \\
\text { dimethylindole }\end{array}$ & $-25,19$ \\
\hline 11 & $\begin{array}{l}\text { Acrylonitrile } \quad \beta-[3-(2,2 \\
\text { dimethylcyclopropyl)-2,2- } \\
\text { dimethylcyclopropyl }\end{array}$ & $-21,93$ & 23 & $\begin{array}{l}\text { 9,9-Dimethoxybicyclo } \\
\text { nona-2,4-dione }\end{array}$ & $-22,52$ \\
\hline 12 & $\begin{array}{l}3,7,11,15 \text {-Tetramethyl-2- } \\
\text { hexadecen-1-ol }\end{array}$ & $-36,59$ & 24 & $\begin{array}{l}\text { 2,7-Dioxa-tricyclo } \\
\text { deca-4,9 diene }\end{array}$ & $-15,29$ \\
\hline
\end{tabular}

molekul dilakukan validasi metode dengan penambatan molekul ulang ligan natif, NDGA dengan 5-LOX untuk mengetahui reliabilitas protokol penambatan molekul. Hasil repenambatan molekul 5-LOX dengan ligan natifnya menghasilkan nilai RMSD $<2$ $\AA$, artinya metode tersebut dapat digunakan untuk skrining senyawa secara virtual. ${ }^{21}$

Hasil dengan menggunakan DOCK 6.9 berupa grid score yang merupakan hasil penjumlahan energi Van der Waals dan energi elektrostatik. Grid score yang semakin negatif mengindikasikan ikatan yang semakin baik antara ligan dengan reseptor. ${ }^{16}$

Pada kompleks zileuton-5-LOX terdapat 6 ikatan hidrogen yang melibatkan asam amino asam aspartat pada urutan ke290 (ASP290) dan glisin pada urutan ke-291 (GLY291) dari reseptor. Dari 23 senyawa uji hanya 7 senyawa yang berikatan dengan ASP290, yaitu senyawa nomor 4, 6. 17, 18, 21, 22 dan 24. Sementara itu, senyawa uji yang berikatan dengan GLY291 adalah senyawa nomor 24. Dari 7 senyawa tersebut hanya senyawa nomor 17 , levodopa yang memiliki grid score lebih rendah dibandingkan zileuton, yaitu $-30,38 \mathrm{kkal} / \mathrm{mol}$.

Di antara 23 senyawa, afinitas tertinggi ditunjukkan oleh n-Hexadecanoic acid dengan grid score terendah $-37,68 \mathrm{kkal} / \mathrm{mol}$. Hal itu juga menunjukkan bahwa afinitasnya lebih tinggi dibandingkan dengan zileuton sebagai obat pembanding yang membutuhkan energi lebih besar untuk berinteraksi dengan 5-LOX, yaitu $-26,19 \mathrm{kkal} / \mathrm{mol}$.

Padakompleksn-Hexadecanoic aciddan 5-LOX hasil molecular penambatan molekul terdapat 1 ikatan hidrogen, yaitu H32 pada n-Hexadecanoic acid dengan -O pada asam amino prolin576 reseptor (jarak 1,89 $\AA$ ) dan 1 ikatan hidrofobik, yaitu pada alkil prolin 575 reseptor dan alkil n-Hexadecanoic acid (jarak 4,77 ̊). Meskipun n-Hexadecanoic acid tidak berikatan pada sisi yang sama dengan zileuton seperti levodopa, tetapi senyawa ini yang dipilih sebagai kandidat obat antiinflamasi yang baru dan diharapkan diuji lebih lanjut aktivitasnya terhadap 5-LOX. Hal tersebut dikarenakan levodopa telah dikembangkan dan beredar di pasaran bukan hanya sebagai obat anti-inflamasi, tetapi juga untuk penyakit Parkinson. 
Tabel 3. Hasil Prediksi Lipinski's Rule Of Five

\begin{tabular}{|c|c|c|c|}
\hline No & Senyawa & Jenis Ikatan & Atom yang Berikatan \\
\hline \multirow[t]{6}{*}{1} & Zileuton (senyawa pembanding) & Hidrogen & *A:H22 - B:ASP290:OO2 \\
\hline & & Hidrogen & A:HO1 - B:ASP290:OD1 \\
\hline & & Hidrogen & B:GLY291:N - A \\
\hline & & Hidrogen & A:H22 - B:ASP290:OD2 \\
\hline & & Hidrogen & A:HO1 - B:ASP290:OD1 \\
\hline & & Hidrogen & B:GLY291:N - A \\
\hline \multirow[t]{4}{*}{2} & 15-Chloro-4-pentadecyne & Hidrofobik & B:PRO256 - A:H04 \\
\hline & & Hidrofobik & B:MET261 - B:ILE337 \\
\hline & & Hidrofobik & A:H04 - B:ILE337 \\
\hline & & Hidrofobik & A:H04 - B:MET261 \\
\hline \multirow[t]{6}{*}{3} & 4-(2-Methoxyphenyl)piperidine & Hidrogen & A:H8 - B:PRO574:O \\
\hline & & Hidrogen & A:H9 - B:THR590:OG1 \\
\hline & & Hidrogen & B:THR577:N - A \\
\hline & & Hidrofobik & B:PRO576 - A \\
\hline & & Hidrofobik & A:C12 - B:PRO574 \\
\hline & & Hidrofobik & A - B:PRO576 \\
\hline \multirow[t]{4}{*}{4} & Cyclobutanol & Hidrogen & B:GLN329:N - A:EA02:O1 \\
\hline & & Hidrogen & A:EA02:H8 - B:ASP290:OD1 \\
\hline & & Hidrogen & A:EA02:H1 - B:ASN328:OD1 \\
\hline & & Hidrofobik & A:EA02 - B:ILE330 \\
\hline \multirow[t]{6}{*}{5} & 1-Hexadecyne & Hidrogen & A:EA04:H30 - B:PRO576:O \\
\hline & & Hidrofobik & B:PRO575 - A:EA04 \\
\hline & & Hidrofobik & A;EA04 - B:LEU305 \\
\hline & & Hidrofobik & A:EA04:C16 - B:LEU327 \\
\hline & & Hidrofobik & A:EA04:C16 - B:PRO575 \\
\hline & & Hidrofobik & B:PHE304 - A:EA04 \\
\hline \multirow[t]{3}{*}{6} & 2-Propylmanonic acid & Hidrogen & A:EA03:H9 - B:ILE292:O \\
\hline & & Hidrogen & A:EA03:H10 - B:ASP290:OD1 \\
\hline & & Hidrofobik & A:EA03:C3 - B:LEU305 \\
\hline \multirow[t]{2}{*}{7} & n-Hexadecanoic acid & Hidrogen & A:H32 - B:PRO576:O \\
\hline & & Hidrofobik & B:PRO575 - A \\
\hline 8 & 2-Hexylacrylonitrile & Hidrogen & B:ASN335:ND2 - A:EA05:N1 \\
\hline \multirow[t]{5}{*}{9} & 3,7,11-Trimethyl-1,6,10-dodecatrien-3-ol & Hidrogen & B:ASN328:ND2- A:H02:O1 \\
\hline & & Hidrogen & A:H02:H17 - B:GLU334:O \\
\hline & & Hidrofobik & B:PRO575 - A:H02 \\
\hline & & Hidrofobik & A:H02:C10 - B:PRO574 \\
\hline & & Hidrofobik & A:H02:C10 - B:PRO575 \\
\hline 10 & $\begin{array}{l}8 \mathrm{a}-\mathrm{M} \text { ethy } \mathrm{lh} \text { ex ahydro- } 1,8(2 \mathrm{H}, 5 \mathrm{H})- \\
\text { naphthalenedione }\end{array}$ & Hidrogen & B:ILE337:N - A:O1 \\
\hline \multirow[t]{2}{*}{11} & Acrylonitrile $\quad \beta$-[3-(2,2-dimethylcyclo & Hidrogen & $\mathrm{B}: \mathrm{ASN} 328: \mathrm{ND} 2$ - A:N1 \\
\hline & propyl)-2,2-dimethylcyclopropyl & Hidrofobik & B:ALA307 - A:C10 \\
\hline 12 & 3,7,11,15-Tetramethyl-2-hexadecen-1-ol & Hidrogen & A:EA07:H40 - B:ASN328:OD1 \\
\hline
\end{tabular}




\begin{tabular}{|c|c|c|c|}
\hline No & Senyawa & Jenis Ikatan & Atom yang Berikatan \\
\hline & & Hidrofobik & B:PRO575 - A:EA07 \\
\hline & & Hidrofobik & A:EA07:C10 - B:ILE330 \\
\hline & & Hidrofobik & A:EA07:C18 - B:PRO574 \\
\hline \multirow[t]{2}{*}{13} & Z-2-Dodecenol & Hidrogen & A:H01:H24 - B:GLU334:O \\
\hline & & Hidrofobik & A:H01 - B:ILE330 \\
\hline \multirow[t]{4}{*}{14} & 15-Chloro-4-pentadecyne & Hidrofobik & B:PRO256 - A:EA08 \\
\hline & & Hidrofobik & A:EA08 - B:ILE337 \\
\hline & & Hidrofobik & A:EA08 - B:MET261 \\
\hline & & Hidrogen & A:EA09:H39 - B:ILE330:O \\
\hline 15 & 2-Methylenecholestan-3-ol & Hidrogen & A:EA09:H39 - B:ILE330:O \\
\hline \multirow[t]{3}{*}{16} & L- Alanine & Hidrogen & A:W01:H5 - B:LEU289:O \\
\hline & & Hidrogen & A:W01:H7 - B:ILE292:O \\
\hline & & Hidrogen & A:W01:H1 - B:LEU305:O \\
\hline \multirow[t]{4}{*}{17} & Levodopa & Hidrogen & A:W06:H9 - B:LEU289:O \\
\hline & & Hidrogen & A:W06:H10 - B:ASP290:OD1 \\
\hline & & Hidrogen & A:W06:H11 - B:ILE292:O \\
\hline & & Hidrogen & A:W06:H3 - B:ASN328:OD1 \\
\hline \multirow[t]{6}{*}{18} & Glycylsarcosine & Hidrogen & B:LEU305:N - A:W03:N2 \\
\hline & & Hidrogen & A:W03:H10 - B:ASP290:OD1 \\
\hline & & Hidrogen & A:W03:H4 - B:LEU305:O \\
\hline & & Hidrogen & A:W03:H4 - B:ASN328:OD1 \\
\hline & & Hidrogen & A:W03:H6 - B:ILE292:O \\
\hline & & Hidrogen & A:W03:H7 - B:ILE292:O \\
\hline \multirow[t]{6}{*}{19} & 5-Hydroxymethylfurfural & Hidrogen & B:THR577:N - A:W04:O2 \\
\hline & & Hidrogen & B:THR590:OG1 - A:W04:O3 \\
\hline & & Hidrogen & A:W04:H5 - B:PRO574:O \\
\hline & & Hidrogen & A:W04:H5 - B:THR590:OG1 \\
\hline & & Hidrofobik & B:PRO575:C,O;PRO576:N - A:W04 \\
\hline & & Hidrofobik & A:W04 - B:PRO576 \\
\hline \multirow[t]{5}{*}{20} & 10-Undecyn-1-ol & Hidrogen & A:EA06:H19 - B:GLU334:O \\
\hline & & Hidrogen & A:EA06:H20 - B:LEU289:O \\
\hline & & Hidrofobik & B:ALA307 - A:EA06 \\
\hline & & Hidrofobik & B:ALA307 - A:EA06:C11 \\
\hline & & Hidrofobik & A:EA06:C11 - B:LEU305 \\
\hline 21 & $\begin{array}{l}2,5 \text {-Dimethyl-2,3-dihydro- } 5 \mathrm{H}-1,4 \text { - } \\
\text { dioxepine }\end{array}$ & Hidrogen & A:H12 - B:ASP290:OD1 \\
\hline \multirow[t]{6}{*}{22} & 4-Nitro-5-hydroxy-1,2-dimethylindole & Hidrogen & B:GLN329:N - A:H03:O2 \\
\hline & & Hidrogen & A:H03:H3 - B:ILE292:O \\
\hline & & Hidrogen & A:H03:H4 - B:ILE292:O \\
\hline & & Elektrostatik & B:ASP290:OD1 - A:H03 \\
\hline & & Elektrostatik & B:ASP290:OD1 - A:H03 \\
\hline & & Hidrofobik & A:W05 - B:LEU305 \\
\hline
\end{tabular}




\begin{tabular}{|c|c|c|c|}
\hline No & Senyawa & Jenis Ikatan & Atom yang Berikatan \\
\hline \multirow{4}{*}{23} & \multirow{4}{*}{ 9,9-Dimethoxybicyclo[3.3.1]nona-2,4-dione } & Hidrofobik & A:H03:C9 - B:LEU305 \\
\hline & & Hidrofobik: & A:H03 - B:ALA307 \\
\hline & & Hidrogen & B:ILE337:N - :A:O3 \\
\hline & & Hidrogen & A:H14 - B:GLY332:O \\
\hline \multirow[t]{5}{*}{24} & \multirow{5}{*}{$\begin{array}{l}\text { 2,7-Dioxa-tricyclo[4.4.0.0 }(3,8)] \text { deca-4,9 } \\
\text { diene }\end{array}$} & Hidrogen & B:GLY291:N - A:W05:O1 \\
\hline & & Hidrogen & A:W05:H1 - B:ASP290:OD1 \\
\hline & & Hidrogen & A:W05:H2 - B:ILE292:O \\
\hline & & Hidrogen & A:W05:H3 - B:ASN328:OD1 \\
\hline & & Hidrofobik & B:ALA307 - A:W05 \\
\hline
\end{tabular}

* Chain A adalah epitop dan chain B adalah reseptor.

\section{Simpulan}

Senyawa pada daun Hemigraphis alternata yang memiliki afinitas paling besar dalam menghambat 5-LOX adalah n-Hexadecanoic acid. Afinitas tersebut lebih besar dibandingakan zileuton sebagai obat pembanding. Hal itu menunjukkan bahwa daun Hemigraphis alternata mengandung komponen aktif potensial yang dapat dikembangkan sebagai obat anti-inflamasi.

\section{Daftar Pustaka}

1. Knoops B, Argyropoulou V, Becker S, Ferté L, Kuznetsova O. Multiple roles of peroxiredoxins in inflammation. Molecules and Cells. 2016; 39(1); 60-4.

2. Loi F, Córdova LA, Pajarinen J, Lin TH, Yao Z, Goodman SB. Inflammation, fracture and bone repair. Bone. 2016; 86: 119-30.

3. Praja MH, Oktarlina RZ. Uji Efektivitas daun petai cina (Laucaena glauca) sebagai antiinflamasi dalam pengobatan luka bengkak. Jurnal Majority. 2017; 6(1): 603 .

4. Leonard BE. Inflammation and depression: a causal or coincidental link to the pathophysiology?. Acta Neuropsychiatrica. 2018; 30(1): 1-6.

5. Efron N. Contact lens wear is intrinsically inflammatory. Clinical and Experimental Optometry. 2017; 100(1): 3-19.

6. Ming WK. Bioassay-guided purification and identification of chemical constituents from Hemigraphis alternata (disertasi). Malaysia: Monash University: 2019.

7. Adangampurath S, Sudhakaran S. Anti- inflammatory potential of flavonoids from Hemigraphis colorata. Int. J. of Life Sciences. 2018; 6(2): 569-74.

8. Arun KK, Nimmanapalli PR, Chaitanya RK, Roy K. Ethyl acetate extract of Hemigraphis colorata leaves shows anti-inflammatory and wound healing properties and inhibits 5-lipoxygenase and cyclooxygenase- 1 and 2 enzymes. Journal of Medicinal Plants Research. 2013; 7(37) :2783-91.

9. Grosser T, Theken KN, FitzGerald GA. Cyclooxygenase inhibition: pain, inflammation, and the cardiovascular system. Clin. Pharmacol. Ther. 2017; 102(4): 611-22.

10. Abbas A, Lichtman A, Pillai S. Basic immunology e-book: functions and disorders of the immune system. China: Elsevier Health Sciences: 2019.

11. Anna H, Andrei M, Gudmar T, Solveig G, Helga J, Unnur T, et al. The gene encoding 5-lipoxygenase activating protein confers risk of myocardial infarction and stroke. Nat. Genet. 2004; 36(3): 233-9.

12. Viceconti M, Henney A, Morley-Fletcher E. In silico clinical trials: how computer simulation will transform the biomedical industry. Int. J. Clin. Trials. 2016; 3(2): 37-46.

13. Hodos RA, Kidd BA, Shameer K, Readhead BP, Dudley JT. In silico methods for drug repurposing and pharmacology. Wiley Interdiscip. Rev. Syst. Biol. Med. 2016; 8(3): 186-210.

14. Pagadala NS, Syed K, Tuszynski J. Software for molecular docking: a review. 
Biophysical Reviews. 2017; 9(2): 91-102.

15. Yuriev E, Holien J, Ramsland PA. Improvements, trends, and new ideas in molecular docking: 2012-2013 in review. Journal of Molecular Recognition. 2015; 28(10): 581-604.

16. Atmajani W, Kurniawan AB, Hapsari R, Santoso B. Kajian in silico agonis PPAR gamma-receptor protein ( $5 \mathrm{Y} 2 \mathrm{O}$ ) sebagai antihiperglikemia menggunakan dock6. The 9th University Research Colloqium (Urecol). 2019; 9(5): 193-200.

17. Manna A, Dian M, Hudiyanti D, Siahaan P. Molecular Docking of interaction between e-cadherin protein and conformational structure of cyclic peptide ADTC3 (Ac-CADTPC-NH2) Simulated on 20 ns. J. Kim. Sains dan Apl. 2017; 20(1): 30-6.

18. Hengphasatporn K, Garon A, Wolschann $\mathrm{P}$, Langer $\mathrm{T}$, Yasuteru $\mathrm{S}$, Huynh TN, Chavasiri W, Saelee T, Boonyasuppayakorn S, Rungrotmongkol
$\mathrm{T}$, et al. Multiple virtual screening strategies for the discovery of novel compounds active against dengue virus: A hit identification study. Sci. Pharm.. 2020; 88(1): 1-19.

19. Murgueitio MS, Bermudez M, Mortier J, Wolber G. In silico virtual screening approaches for anti-viral drug discovery. Drug Discovery Today: Technologies. 2012; 9(3): 219-25.

20. Meng XY, Zhang HX, Mezei M. Cui M. Molecular Docking: A powerful approach for structure-based drug discovery. Curr. Comput. Aided-Drug Des. 2011; 7(2): 146-57.

21. Musoev A, Numonov S, You Z, Gao H. Discovery of novel DPP-IV inhibitors as potential candidates for the treatment of type 2 diabetes mellitus predicted by 3D QSAR pharmacophore models, molecular docking and de novo evolution. Molecules. 2019; 24(16): 2870-82. 